\title{
Teaching speech acts: Input enhancement versus presentation, practice, and production
}

\author{
Rezvani, Ehsan $\bowtie$ \\ University of Isfahan, Iran (rezvani_ehsan_1982@yahoo.com) \\ Eslami-Rasekh, Abbass \\ University of Isfahan, Iran (abbasseslamirasekh@yahoo.com) \\ Vahid Dastjerdi, Hossein \\ University of Isfahan, Iran (h vahid@yahoo.com)
}

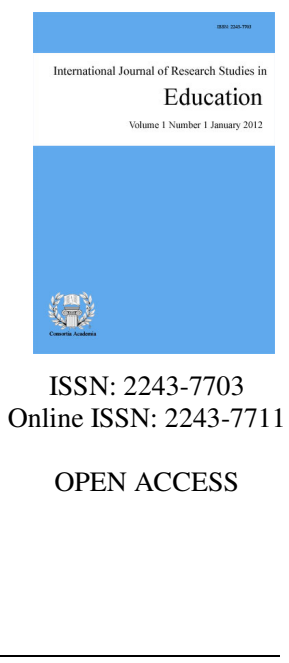

\section{Abstract}

The present study aimed at investigating the potentially facilitative effects of an attention-drawing method of teaching — input enhancement—on the acquisition of the speech acts of requests and suggestions by Iranian EFL learners. Moreover, an attempt was made to compare the relative efficacy of input enhancement in this regard with that of a more traditional method of teaching known as the Presentation, Practice, and Production (PPP) method. Ninety homogenous adult Iranian intermediate EFL learners attending a language institute in Isfahan, Iran, were randomly assigned to three groups: Input enhancement Group (IG), PPP Group (PG) and Control Group (CG). A pre-test was given to the three groups to measure the participants' ability to use requests and suggestions prior to any treatment. Then, all the groups were exposed to short conversations (audio and script) including the speech acts under study. However, while the IG was provided only with typographical enhancement of the requests and suggestions, the researchers applied the PPP method to teach the speech acts in focus to the students in the PG. The students in the CG received a placebo task. The results of the post-test, administered after the treatment, indicated that both input enhancement and PPP exerted a significant effect on the learners' production of requests and suggestions in English. It was also found that the participants who were taught through PPP outperformed those in the IG; however; the observed difference was not statistically significant. Accordingly, it can be claimed that an implicit and unobtrusive method such as input enhancement can be as effective as a traditional method such as PPP, which requires the execution of extensive mechanical practice and production drills.

Keywords: speech acts; implicit teaching; explicit teaching; input enhancement; PPP 


\section{Teaching speech acts: Input enhancement versus presentation, practice, and production}

\section{Introduction}

A few decades ago research in inter-language pragmatics (ILP) focused mainly on the interaction norms employed in different languages and cultures. Mostly, such research aimed at comparing second language (L2) learners' speech act realization with those of native speakers (Kasper, 1989). More recently, however, research findings indicate that there are considerable differences between L2 learners and native speakers with regard to their perception and production of speech acts (Bardovi-Harlig, 2001). Accordingly, the area of pragmatics in the context of second language acquisition (SLA) has witnessed a surge of interest in studies that examine L2 learners' pragmatic competence. More specifically, research in the last decade has focused on the role of instruction in pragmatic development (for reviews, see Kasper, 2001; Kasper \& Rose, 2002; Martinez-Flor, Usó, \& Fernández, A., 2003), and it has been found that learners who receive instruction on different aspects of pragmatics are at a distinct advantage (Olshtain \& Cohen, 1990; Takahashi, 2001; Rose \& Ng Kwai-Fun, 2001, Safont, 2005 among others).

Two main trends are recognizable in the research on instructed ILP. One group of studies has placed more emphasis on examining the teachability of pragmatic features, pragmatic routines, conversational implicature, discourse strategies, politeness in requests, as well as speech acts (Billmyer, 1990; Eslami-Rasekh, Eslami-Rasekh, A., \& Fatahi, 2004; Fukuya, 1998; Kondo, 2001, 2004; Rose \& Ng Kwai-Fun, 2001; Yoshimi, 2001, to mention a few). These studies have employed an explicit focus on forms (FonFS) approach and they have investigated the effects of explicit teaching of pragmatics by providing meta-pragmatic information. Another group of studies on instructed ILP has focused mainly on comparing the effects of explicit and implicit instruction on L2 pragmatic awareness and development (House, 1996; Pearson, 2001; Takahashi, 2001; Tateyama, 2001; Tateyama, Kasper, Mui, Tay, \& Thananart, 1997).

Kasper and Rose (2002) argue that there is an urgent need for further research on the role of instruction on learners' pragmatic development in the EFL classroom because learners in EFL contexts suffer from insufficient exposure to the target language and lack of opportunities to use the target language for real-life purposes. Given the scarcity of research in this regard, the ultimate goal of this study was to contribute to the increasing body of research in the relatively young field of ILP in general and more specifically to that dealing with the effects of pragmatic instruction in the EFL context in Iran. Furthermore, we hoped to make improvements over the previous studies by a more concrete operationalization of two teaching approaches.

This being so, the present study aimed at investigating the potential effects of input enhancement on Iranian EFL learners' production of the speech acts of request and suggestion in English. Moreover, this study sought to compare the facilitative effects of input enhancement with that of PPP on the production of requests and suggestions.

\section{Background of the study}

\subsection{Research on ILP}

Findings of research conducted on the effects of instruction on pragmatics in SLA have indicated positive effects of such efforts (Kasper, 2001). Most of these studies, which employed explicit instruction where learners were provided with explicit meta-pragmatic information through explanation, description and discussion of speech acts, have lent support to facilitative effects of explicit instruction (Billmyer, 1990; Takahashi, 2001; Rose \& Ng Kwai-Fun, 2001; Tateyama, 2001). In other words, it has been concluded that receiving explicit instruction promotes learners' ability to express more native-like speech acts. 
Teaching speech acts: Input enhancement versus presentation, practice, and production

Nevertheless, fewer studies, focusing on how implicit instruction leads to pragmatic learning, have presented inconclusive results. For instance, while Martinez-Flor (2004) has demonstrated how L2 learners can benefit from implicit instruction in their pragmatic development, Fukuya and Clark (2001) and Fukuya, Reeve, Gisi, \& Christianson (1998) have reported insignificant effects of certain types of implicit instruction on pragmatic learning.

\subsection{Visual input enhancement}

Over the past years, an increasingly well-established line of work has emerged which has primarily stressed the role of attention and awareness in SLA learning contexts (Schmidt, 1990, 1995). Following the same line of research, drawing the learners' attention to certain characteristics of language which might otherwise go unnoticed has gained considerable importance. This method of instruction, which aims at heightening metalinguistic awareness, has come to be known as 'input (salience) enhancement' (Sharwood Smith, 1991, 1993). Sharwood Smith, who introduced 'input enhancement' as a way of directing learners' attention to formal aspects of language information, has noted that we can make the input salient by manipulating different aspects of it. Manipulation of input often takes the form of visual input enhancement in which the target forms are made visually salient via such techniques as highlighting, bolding, underlining, color coding, etc. This study is an attempt to examine the role of visual input enhancement in teaching an important area of pragmatics—speech acts.

\subsection{Research questions}

The research questions under investigation were as follows:

$>$ Does input enhancement exert a significant effect on Iranian EFL learners' production of linguistically accurate and pragmatically appropriate requests and suggestions?

$>\quad$ Does PPP have a significant effect on Iranian EFL learners' production of linguistically accurate and pragmatically appropriate requests and suggestions?

$>$ Is there a significant difference between input enhancement and PPP with regard to the influence these two approaches to teaching exert on EFL learners' production of linguistically accurate and pragmatically appropriate requests and suggestions?

\section{Method}

\subsection{Participants}

The participants in this study were 120 Iranian intermediate EFL learners, aged 19-27, attending a language institute Isfahan, Iran. In order to make sure in objective terms that these learners were truly homogenous with regard to their English proficiency level, a Nelson English Language Proficiency Test (Fowler \& Coe, 1976) was given to them. Having obtained the proficiency test results, the researchers decided to choose those participants whose score range fell one standard deviation above and below the mean (i.e. mean \pm 1 ). This being so, 90 students met this homogeneity criterion and were thus selected to serve as the participants of this study. Later, they were randomly assigned to the three groups (two experimental and one control) involved in the study (30 students each).

\subsection{Instructional foci}

The instructional foci in this study were eighteen different structures to perform the speech acts of request and suggestion in English. These target forms were selected from three English teaching series: New Interchange, 3rd Edition: Richards et al. (2005); American Headway: Soars and Soars (2001), and Top Notch: Saslow and 
Rezvani, E., Eslami-Rasekh, A., \& Vahid Dastjerdi, H.

Ascher (2006). The request and suggestion patterns in focus were classified into two categories according to the socio-pragmatic factors of formality and status:

Equal status and informal patterns (equal status between the speaker and the interlocutor) included:

$>\quad$ Requests: Will you open the door? Can I use your pen? Could you lend me ten bucks? Is it OK if I use your pen?; Do you mind if I use your camera?

$>$ Suggestions: Why don't you see a doctor? May be you could talk to the boss; What about going on a trip? You'd be better off making reservation in advance.

Higher status and formal pattern (higher status of an interlocutor than that of the speaker) included:

$>\quad$ Requests: Would it be OK if I borrowed your car tomorrow?; Would you mind if I used your cell phone? Would you mind opening the door?; I wonder if I could borrow some money? I was wondering if you'd mind lending me your car?

$>$ Suggestions: It might be a good idea to take a day off; What is commonly recommended is to withdraw the money; Have you considered talking to her about it; One thing you could do is to take a course on it.

\subsection{Procedures and treatment}

The experimental sequence of the study was carried out over a period of around twelve weeks. As noted earlier, 90 homogenous learners were randomly assigned to three groups: Input enhancement Group (IG), PPP Group (PG) and Control Group (CG). One week prior to the first treatment session, all the participants took the pre-test which was a ten-item Discourse Completion Task (DCT) designed to elicit the request and suggestion speech acts in different situations and assess the learners' knowledge of these prior to any type of treatment (see Appendix A for sample items of the pre- and the post-test). Then, every group underwent ten different treatment sessions. There was an interval of around 5 or 6 days between the treatment sessions, and the post-test (another DCT with different items) followed the last teaching session a week later. In an attempt to control for outside exposure to the target form, after completing the post-test, the learners were asked whether they had consulted with anyone or anything about the target form. The data from those who reported having done so were discarded. For this reason, the groups slightly differed in size; there were 25, 24, 23 participants in the IG, PG and CG, respectively.

The instruction for the PG was characterized by explicitness and deduction followed by a variety of drills. In teaching the target forms to this group, the researchers applied a traditional method of teaching, which is composed of three major phases of Presentation, Practice, and Production, often referred to as the "PPP" method. Underlying this method of teaching is the assumption that the teacher should first present the data to the students, then a variety of drills (such as repetition, substitution, transformation, etc.) should be undertaken, and that, finally, through a number of question-answer drills, the students should be given a chance to produce the given structures. Therefore, PG students first listened to a short conversation including the requests and suggestions in focus. Then, they received a scripted version of the conversation, and participated in a series of direct awareness-raising (i.e., listening to the teacher's explanations about grammatical rules involved and the meta-pragmatic information on the appropriateness of use) and productive (i.e., repetition, role-plays, etc.) activities.

The students in the IG were taught via visual input enhancement. After listening to the same conversations, they received the script in which the target forms (i.e., requests and suggestions in focus) appeared in bold (See Appendix C for sample excerpts). That is, unlike the PG students for whom the target forms appeared in plain text-type, IG students were provided with typographical enhancement of the target forms. The purpose of using input enhancement was to indirectly draw learners' attention to forms, function and appropriate usage without 
Teaching speech acts: Input enhancement versus presentation, practice, and production

embarking on explanation about grammar or meta-pragmatic information about appropriate use. Moreover, input enhancement was employed to free the teacher and learners of any kind of language practice tasks such as mechanical and production drills. Those in the control group listened to the conversations and were given a placebo task of having a classroom discussion about how English native speakers open up and terminate conversations.

\subsection{Tests and scoring procedures}

A pre-test and a post-test were constructed by the researchers to assess the participants' knowledge of the speech acts in focus prior to and after the treatment phase of the study. Both tests were DCTs constituting ten different situations to which the students were required to respond by providing a request or a suggestion. The participants' responses to pre- and post-test items (their use of requests and suggestions) were scored considering the type of language used; that is, each linguistically accurate and pragmatically appropriate request or suggestion was given a single point. Answers which were grammatical but not pragmatically appropriate or vice versa were given half a point, and answers which were neither grammatical nor appropriate were given zero. For each participant, the correct answers were added up to obtain the total score. It should be noted that following Trosborg's proposal (1995) on request realization strategies, the appropriateness of the requests was decided upon considering two variables: social distance of the interlocutors and the size of the favour.

Since the pre- and post-test were made by the researchers, we piloted both tests prior to the study. An alpha Cronbach method was applied to ascertain the tests' reliability. Having done so, the reliability indexes revealed that the two tests were acceptable for the purpose of the present study. Moreover, two experts in the field examined the tests and ensured us about their validity.

\section{Statistical analyses and results}

\subsection{Pre-test of the study}

The pre-test was to ensure the researchers that the learners in the experimental and control groups enjoyed the same level of knowledge regarding the speech acts under investigation. Table 1 shows the descriptive statistics of the participants' mean scores on the pre-test across the three groups.

Table 1

Descriptive statistics on the pre-test

\begin{tabular}{llccrc}
\hline Groups & $\mathrm{N}$ & Minimum & Maximum & Mean & SD \\
\hline IG & 25 & 3.50 & 7.00 & 4.7987 & 1.17251 \\
PG & 24 & 2.00 & 7.50 & 4.8521 & 1.08321 \\
CG & 23 & 3.00 & 6.00 & 4.7250 & 1.10540 \\
\hline
\end{tabular}

It can be seen in the above table that the mean scores for the three groups are statistically very close (IG: 4.7987 $\approx$ PG: $4.8521 \approx C G: 4.7250$ ). Therefore, it can be concluded that the learners in the three groups did not differ greatly from one another in terms of their knowledge of the target forms in question.

\subsection{Research question 1}

The first research question focused on whether input enhancement exerts a significant influence on the acquisition of requests and suggestions by Iranian intermediate EFL learners. To investigate the impact of input enhancement on the participants' production of requests and suggestions, a paired-samples t-test was run. The t-test was intended to compare the obtained mean scores of the participants in the IG on the pre- and post-tests to indicate the effectiveness of the treatment. The descriptive statistics, along with the results of the t-test for the IG, are presented in Tables 2 and 3, respectively. 
Rezvani, E., Eslami-Rasekh, A., \& Vahid Dastjerdi, H.

Table 2

Descriptive statistics for the $I G$

\begin{tabular}{clccc}
\hline \multicolumn{1}{c}{ Mean } & N & SD & Std. Error Mean \\
\hline Pair & Pre-test 4.7987 & 25 & 1.17251 & .22116 \\
1 & Post-test 7.9125 & 25 & 1.17412 & .21852 \\
\hline
\end{tabular}

Table 3

Paired-samples t-test results for the IG

\begin{tabular}{ccccc}
\hline Mean & SD & t & df & Sig. (2-tailed) \\
\hline Pre/post-test 3.02542 & 1.43213 & 10.760 & 24 & .000 \\
\hline
\end{tabular}

Given the information in Table 2, one can clearly see that the mean score obtained on the post-test (7.9125) is higher than the one obtained on the pre-test (4.7987). However, a paired-samples t-test was run to ensure that the observed difference was significant. Table 3 shows that there is a significant difference between the scores obtained from the pre- and post-tests $(p<0.05)$. Accordingly, it can be claimed that input enhancement was shown to exert a positive effect on the acquisition of the given speech acts.

\subsection{Research question 2}

The second research question examined whether the PPP method has a significant effect on the acquisition of requests and suggestions by Iranian intermediate EFL learners. To answer this question, a paired-samples t-test was conducted. Tables 4 and 5 provide the descriptive statistics, along with the results of the given paired-samples t-test.

\section{Table 4}

Descriptive statistics for the $P G$

\begin{tabular}{|c|c|c|c|c|}
\hline & Mean & $\mathrm{N}$ & SD & Std. Error Mean \\
\hline Pair & Pre-test 4.8521 & 24 & 1.08321 & .20631 \\
\hline 1 & Post-test 7.9440 & 24 & 1.30019 & .18715 \\
\hline
\end{tabular}

Table 5

Paired-samples t-test results for the $P G$

\begin{tabular}{ccccc}
\hline Mean & SD & t & df & Sig. (2-tailed) \\
\hline Pre/post-test 2.65197 & 1.20271 & 10.509 & 23 & .000 \\
\hline
\end{tabular}

On a closer inspection of the mean scores given in Table 4, one can clearly see that the participants in PG gained a higher mean score on the post-test after receiving the treatment (Pos-test=7.9440>Pre-test=4. 8521). However, the researchers had to go further to find out whether or not the observed difference was significant. Therefore, the results of the t-test were taken into account. It can be concluded from the information presented in Table 5 that there is a significant difference between the performance of the participants on the pre- and post-tests $(.000<0.05)$. In sum, it can be concluded that the PPP method has a positive impact on the Iranian intermediate EFL learners' production of requests and suggestions.

\subsection{Research question 3}

The last research question focused on whether there is a significant difference between input enhancement and PPP with regard to the influence these two approaches to teaching exert on the production of some requests and suggestions by Iranian intermediate EFL learners. To answer this question, a one-way between-groups ANOVA was conducted. Table 6 provides the results of the ANOVA. 
Teaching speech acts: Input enhancement versus presentation, practice, and production

Table 6

The results of ANOVA on the post-test

\begin{tabular}{lclll}
\hline & Sum of Squares & df & Mean Square & f Sig. \\
\hline Between Groups & 112.551 & 2 & 56.488 & 40.286 .000 \\
Within Groups & 107.430 & 69 & 1.552 & \\
Total & 219.982 & 71 & & \\
\hline
\end{tabular}

On a closer inspection of Table 6 , one can conclude that the three groups differed significantly with respect to their mean scores on the post-test $(.000<0.05)$. However, Table 6 does not show where the observed differences lie. Therefore, a Scheffe Post-hoc Test was run. Table 7 provides the results of the post-hoc test.

Table 7

The results of the Post-hoc test

\begin{tabular}{llllll}
\hline & \multicolumn{2}{l}{$\begin{array}{l}\text { Mean Std. Error } \\
\text { (I) Teaching (J) Teaching }\end{array}$} & \multicolumn{3}{c}{$\begin{array}{l}\text { Sig. 95\% confidence interval } \\
\text { Differences }\end{array}$} \\
\hline IG PG & .26975 & .32494 & .674 & -.5325 & 1.0902 \\
CG & $2.70650 *$ & .31620 & .000 & 1.8860 & 3.5347 \\
PG IG & -.26975 & .32494 & .674 & -1.0902 & .5325 \\
CG & $2.42415^{*}$ & .32760 & .000 & 1.6137 & 3.2556 \\
CG IG & $-2.70650^{*}$ & .31620 & .000 & -3.5347 & -1.8860 \\
PG & $-2.42415^{*}$ & .32760 & .000 & -3.2556 & -1.6137 \\
\hline Note. * The mean difference is significant at the .05 level. & & &
\end{tabular}

In the first row of the table, the asterisk next to 2.70650 indicates that the difference between the IG and the CG is significant. Likewise, the difference between the PG and the CG appears to be significant because an asterisk can be seen next to 2.42415 in the second row of the table. In a nutshell, it can be claimed that the performance of the IG and PG was significantly different from that of the CG, but there seems to be no significant difference between the IG and PG. As a result, it can be claimed that there is no significant difference between input enhancement and PPP in terms of the influence they exert on the production of requests and suggestions.

\section{Discussion}

This study was an attempt to investigate three research questions: (1) whether input enhancement exerts a significant effect on the acquisition of requests and suggestions by Iranian EFL learners; (2) whether the traditional method of teaching known as the Presentation, Practice, and Production (PPP) has a significant effect on the acquisition of requests and suggestions; and (3) whether there is a significant difference between input enhancement and PPP with regard to the influence these two methods exert on the acquisition of requests and suggestions. In brief, it was revealed that both methods have a positive impact on the acquisition of the target forms. Moreover, the findings indicated that these two methods were not significantly different with regard to the influence they exerted on the acquisition of the target forms.

Firstly, the results demonstrating that the learners who were taught through input enhancement made significant gains with regard to the production of requests and suggestions concurs with the general findings of earlier studies on the facilitative effects of input enhancement (Doughty, 1991; Longman, 1995; Shook, 1994;Williams, 1999). It should be noted that studies on the effects of implicit methods of instruction such as input enhancement on L2 learners' pragmatic development have produced mixed results. Fukuya et al. (1998) reported that implicit instruction was not effective in teaching pargamtics in comparison with explicit instruction. However, the present findings lend further support to those studies which have demonstrated positive effects of input enhancement on the acquisition of speech acts (Alcon, 2005; Fukuya \& Clark, 2001; Martinez-Flor, 2004).

Secondly, the fact that learners who were taught via PPP did significantly better on the post-test suggests that explicit methods of instruction such as PPP can be effective in leading the learners to produce linguistically accurate and pragmatically appropriate requests and suggestions. This is in line with previous studies that report 
the benefits of explicit instruction for L2 pragmatic development (Billmyer, 1990; Bouton, 1994; Rose \& Ng Kwai-fun, 2001; Safont, 2003, 2004, 2005; Takahashi, 2001). More specifically, findings with regard to the second research question in this study lend further support to those studies on the positive effects of explicit instruction which employed explanation and discussion of rules as their approach to provide learners with meta-pragmatic information (Kubota, 1995; LoCastro, 1997; Trosborg, 2003; Wishnoff, 2000; Yoshimi, 2001). The results of the present study, in line with the aforementioned studies, indicate that learners' ability to express more native-like speech acts will improve with explicit instruction, although whether or not that knowledge is retained over time is questionable. Moreover, the significant improvement of the PG in the production of requests and suggestions in this study can be justified considering Bialystok's position (1993) on two cognitive components of language processing - analysis of knowledge and control of processing. Since PG learners received explicit explanation of rules regarding both accuracy and appropriateness of requests, their pragmatic knowledge must have been developed in terms of metalinguistic knowledge and the relations between forms and appropriate use. On the whole, the application of explicit methods such as PPP in foreign/second language teaching has been advocated by researchers who believe in the insufficiency of implicit instruction as a means of inducing changes in the learners' inter-language system (Izumi, 2002; Jourdenias, 1998; White, 1998).

Thirdly, in relation to the effects of input enhancement versus PPP on the learners' production of requests and suggestions, it should be noted that the present findings run counter to those of several other studies (Alcon, 2005; House \& Casper, 1981; Rose \& Ng Kwai-Fun, 2001; Takahashi, 2001) which have reported that the groups, who received explicit instruction, had a significant advantage in their gains over those learners who were taught via more implicit methods. In line with the results reported by Martinez-Flor (2004), this study revealed that those students who received explicit instruction did outperform those in the implicit group; however; the observed difference was not statistically significant. Accordingly, it can be claimed that an implicit and unobtrusive method such as input enhancement can be as effective as an explicit method of instruction such as PPP, which requires the execution of lengthy mechanical and productive drills. Whereas practice cannot take place without some degree of noticing, the obverse is not the case; noticing can occur without practice. Thus, as the results of this study show, it is perfectly possible to teach pragmatics in the sense of helping learners notice and learn the phenomena under study without having them engage in activities that require repeated production of the structures or forms concerned.

\section{Implications and limitations}

This study examined the effects of two methods of instruction on the linguistic accuracy and pragmatic appropriateness of Iranian EFL learners' requests and suggestions in English. The results contribute to the findings of previous research on the facilitative effects of instruction on second and foreign language learning in general (Norris \& Ortega, 2000; Doughty, 2003), and the benefits of input enhancement on the development of learners' pragmatic competence in using requests and suggestions in particular. In the light of the present findings which reveal that an implicit method of instruction can be as effective as an explicit one in teaching speech acts in English, certain pedagogical implications may be proposed. First, a more direct link should be made between ILP research and the field of second language acquisition. In other words, materials developers and instructors should integrate pragmatics into their second and foreign language instruction to better develop learners' pragmatic competence in second and foreign language settings. Second, awareness-raising tasks and input enhancement techniques should be operationalized and implemented by language instructors to equip learners with a better knowledge of pragmatics and to ensure that pragmatic features are attended to by EFL learners. The third pedagogical implication of this study is that it is desirable and advisable to combine two different teaching approaches because some learners might need to receive explicit metapragmatic information, whereas others may benefit more from simple consciousness-raising activities via exposure to target language forms.

As for the limitations of the study, it is worth noting that the target forms used in this study represent only a small portion of the overall range of possible ways for making requests and suggestions. A second limitation of 
Teaching speech acts: Input enhancement versus presentation, practice, and production

our study lies in the population of the learners we dealt with in this study. We believe that the participants' individual variables such as gender and age might have influenced our findings. For instance, previous research has demonstrated the effect of gender on learners' specific use of speech acts (Rose \& Ng Kwai-fun, 2001). Accordingly, we wonder whether another study with either just male or female learners will provide us with different results. Yet another limitation of the present study involves our mere focus on the short term effects of our treatment, leading us to feel the urge for further studies on the long term effects of instruction on speech act use by EFL learners.

\section{References:}

Alcon, E. (2005). Does instruction work for learning pragmatics in the EFL context? System, 33, 417-435. http://dx.doi.org/10.1016/j.system.2005.06.005

Bardovi-Harlig, K. (2001). Evaluating the empirical evidence: grounds for instruction in pragmatics. In K. R. Rose \& G. Kasper (Eds.), Pragmatics in Language Teaching (pp. 13-32). Cambridge: Cambridge University Press. http://dx.doi.org/10.1017/CBO9781139524797.005

Bialystok, E. (1993). Symbolic representation and attentional control in pragmatic competence. In G. Kasper \& S. Blum-Kulka (Eds.), Inter-language Pragmatics (pp. 43-57). Oxford: Oxford University Press.

Billmyer, K. (1990). "I really like your lifestyle": ESL learners learning how to compliment. Penn Working Papers in Educational Linguistics, 6(2), 31-48.

Bouton, L. F. (1994). Can NNS skill in interpreting implicature in American English be improved through explicit instruction? - A pilot study. In L. Bouton (Ed.), Pragmatics and Language Learning, vol. 5 (pp. 88-109). Division of English as an International Language Intensive English Institute, Urbana, IL: University of Illinois at Urbana-Champaign.

Doughty, C. (1991). Second language instruction does make a difference: evidence from an empirical study of SL relativization. Studies in Second Language Acquisition, 13(4), 431-469. http://dx.doi.org/10.1017/S0272263100010287

Doughty, C. (2003). Instructed SLA: Constraints, compensation, and enhancement. In M. H. Doughty \& M. H. Long (Eds.), The Handbook of Second Language Acquisition (pp. 256-310). Oxford: Blackwell. http://dx.doi.org/10.1002/9780470756492.ch10

Doughty, C., \& Williams, J. (Eds.). (1998). Focus on Form in Classroom Second Language Acquisition. Cambridge: Cambridge University Press.

Eslami-Rasekh, Z. (2004). The effect of explicit metalinguistic instruction on the speech act awareness of advanced EFL students. TESL-EJ, 8(2), 1-12.

Fowler, W. S., \& Coe, N. (1976). Nelson English Language Tests. London: Bulter and Tannerltad.

Fukuya, Y. J. (1998). Consciousness-raising of downgraders in requests. Paper Presented at Second Language Research Forum '98, University of Hawai'i at Manoa (ERIC Document Reproduction Service No. ED466100).

Fukuya, Y. J., Reeve, M., Gisi, J., \& Christianson, M. (1998). Does focus on form work for teaching sociopragmatics? Paper Presented at the $12^{\text {th }}$ International Conference on Pragmatics and Language Learning, University of Illinois at Urbana-Champaign (ERIC Document Reproduction Service No. ED 452736).

Fukuya, Y. J., \& Clark, M.K. (2001). A comparison of input enhancement and explicit instruction of mitigators. In L. Bouton (Ed.), Pragmatics and Language Learning (vol. 10, pp. 111-130). Division of English as an International Language Intensive English Institute, Urbana, IL: University of Illinois at Urbana-Champaign.

House, J. (1996). Developing pragmatic fluency in English as a foreign language. Studies in Second Language Acquisition, 18, 225-253. http://dx.doi.org/10.1017/S0272263100014893

House, J., \& Kasper, G. (1981a). Politeness markers in English and German. In F. Coulmas (Ed.), Conversational Routine (pp. 157-185). The Netherlands: Mouton de Gruyter, The Hague.

Izumi, S. (2002). Output, input enhancement, and the noticing hypothesis: An experimental study on ESL 
Rezvani, E., Eslami-Rasekh, A., \& Vahid Dastjerdi, H.

relativization. Studies in Second Language Acquisition, 24, 541-577. http://dx.doi.org/10.1017/S0272263102004023

Jourdenias, R. (2001). Cognition, instruction, and protocol analysis. In P. Robinson (Ed.), Cognition and second language instruction (pp. 58-79). New York: Cambridge University Press. http://dx.doi.org/10.1017/CBO9781139524780.014

Kasper, G. (1989). Variation in inter-language speech act realisation. In S. Gass, C. Madden, D. Preston, \& L. Selinker (Eds.), Variation in second language acquisition, Discourse and Pragmatics (pp. 37-58). Clevedon, Avon: Multilingual Matters.

Kasper, G. (2001). Classroom research on inter-language pragmatics. In K. R. Rose \& G. Kasper (Eds.), Pragmatics in Language Teaching (pp. 33-60). Cambridge: Cambridge University Press.

Kasper, G., \& Rose, K. R. (2002). Pragmatic development in a second language. Mahwah, NJ: Blackwell. http://dx.doi.org/10.1017/CBO9781139524797.006

Kondo, S. (2001). Instructional effects on pragmatic development: refusal by Japanese EFL learners. Publications of Akenohoshi Women's Junior College, 19, 33-51.

Kubota, M. (1995). Teachability of conversational implicature to Japanese EFL learners. The Institute for Research in Language Teaching Bulletin, 9, 35-67.

Leeman, J., Arteagoitia, I., Fridman, B., \& Doughty, C. (1995). Integrating attention to form with meaning: focus on form in content-based Spanish instruction. In R. Schmidt (Ed.), Attention and Awareness in Foreign Language Learning (pp. 217-258). Honolulu, HI: University of Hawai ‘i, Second Language Teaching \& Curriculum Center.

LoCastro, V. (1997). Pedagogical intervention and pragmatic competence development. Applied Language Learning, 8(1), 75-109.

Long, M. H. (1991). Focus-on-form: A design feature in language methodology. In K. De Bot, R. Grinsberg, \& D. Kramsch, (Eds.), Foreign Language Research in Cross-cultural Perspective (pp. 39-52). Amsterdam: John Benjamins. http://dx.doi.org/10.1075/sibil.2.07lon

Martínez-Flor, A. (2004). The effect of instruction on the development of pragmatic competence in the English as a foreign language context: a study based on suggestions. Unpublished Doctoral dissertation, Universitat Jaume I, Castellón, Spain.

Martínez-Flor, A., Usó, E., \& Fernández, A. (Eds.) (2003). Pragmatic Competence and Foreign Language Teaching. Spain: Servei de Publicacions de la Universitat Jaume I, Castellón.

Norris, J., \& Ortega, L. (2000). Effectiveness of L2 instruction: a research synthesis and quantitative metaanalysis. Language Learning 50, (3), 417-528. http://dx.doi.org/10.1111/0023-8333.00136

Olshtain, E., \& Cohen, A.D. (1990). The learning of complex speech act behavior. TESL Canada Journal, 7(2), $45-65$.

Pearson, E. L. (2001). Pragmatics in foreign language teaching: the effects of instruction on L2 learners' acquisition of Spanish expressions of gratitude, apologies, and directives. Unpublished doctoral dissertation, The University of Texas at Austin.

Richards, J. C., Hull, J., \& Proctor, S. (2005). Interchange Series, $3^{\text {rd }}$ Edition. Cambridge: Cambridge University Press.

Robinson, P. (1995). Attention, memory, and the "Noticing" hypothesis. Language Learning, 45, $283-331$. http://dx.doi.org/10.1111/j.1467-1770.1995.tb00441.x

Rose, K. R., \& Ng, C.K. (2001). Inductive and deductive teaching of compliments and compliment responses. In K. R. Rose \& G. Kasper (Eds.), Pragmatics in Language Teaching (pp. 145-170). Cambridge: Cambridge University Press. http://dx.doi.org/10.1017/CBO9781139524797.013

Safont, M. P. (2003). Instructional effects on the use of request acts modification devices by EFL learners. In A. Martínez-Flor, E. Usó, \& A. Fernández (Eds.), Pragmatic Competence and Foreign Language Teaching (pp. 211-232). Spain: Servei de Publicacions de la Universitat Jaume I, Castellón.

Safont, M. P. (2004). An analysis on EAP learners' pragmatic production: a focus on request forms. Ibérica, 8 , 23-39.

Safont, M. P. (2005). Third Language Learners. Pragmatic Production and Awareness. Clevedon: Multilingual 
Teaching speech acts: Input enhancement versus presentation, practice, and production

Matters.

Saslow, J., \& Ascher, A. (2006). Top Notch Series. New York: Pearson education.

Schmidt, R. (1990). The role of consciousness in second language learning. Applied Linguistics, 112, 129-158. http://dx.doi.org/10.1093/applin/11.2.129

Schmidt, R. (1995). Consciousness and foreign language learning: a tutorial on the role of attention and awareness in learning. In R. Schmidt (Ed.), Attention and awareness in foreign language learning (pp. 1-63). Honolulu: Second language teaching and curriculum center.

Schmidt, R. (2001). Attention. In P. Robinson, (Ed.), Cognition and second language instruction (pp. 3-32). Cambridge: Cambridge University Press. http://dx.doi.org/10.1017/CBO9781139524780.003

Sharwood Smith, M. (1991). Speaking to many minds: On the relevance of different types of language information for the L2 learner. Second Language Research, 7, 118-132. http://dx.doi.org/10.1177/026765839100700204

Sharwood Smith, M. (1993). Input enhancement in instructed SLA. Studies in Second Language Acquisition, 15, 165-179. http://dx.doi.org/10.1017/S0272263100011943

Sharwood Smith, M. (1994). Second language learning: Theoretical foundations. New York: Longman.

Shook, D. (1994). FL/L2 reading, grammatical information, and input-to-intake phenomenon. Applied Language Learning, 5, 57-93.

Soars, L., \& Soars, J. (2001). American Headway Series. Oxford: Oxford University Press.

Takahashi, S. (2001). The role of input enhancement in developing pragmatic competence. In K. R. Rose \& G. Kasper (Eds.), Pragmatics in Language Teaching (pp. 171-199). Cambridge: Cambridge University Press. http://dx.doi.org/10.1017/CBO9781139524797.014

Tateyama, Y. (2001). Explicit and implicit teaching of pragmatics routines: Japanese sumimasen. In K. R. Rose \& G. Kasper (Eds.), Pragmatics in Language Teaching (pp. 200-222). Cambridge: Cambridge University Press. http://dx.doi.org/10.1017/CBO9781139524797.015

Tateyama, Y., Kasper, G., Mui, L.P., Tay, H., \& Thananart, O. (1997). Explicit and implicit teaching of Japanese pragmatics routines. In L. Bouton (Ed.), Pragmatics and Language Learning (pp. 163-177). Division of English as an International Language Intensive English Institute, Urbana, IL: University of Illinois at Urbana- Champaign.

Tomlin, R., \& Villa, V. (1994). Attention in cognitive science and SLA. Studies in Second Language Acquisition, 16, 185-204. http://dx.doi.org/10.1017/S0272263100012870

Trosborg, A. (1995). Inter-language pragmatics. Requests, complaints and apologies. Berlin: Mouton de Gruyter. http://dx.doi.org/10.1515/9783110885286

Trosborg, A. (2003). The teaching of business pragmatics. In A. Martínez-Flor, E. Usó, \& A. Fernández (Eds.), Pragmatic Competence and Foreign Language Teaching (pp. 247-281). Castellón, Spain: Servei de Publicacions de la Universitat Jaume I.

White, J. (1998). Getting the learners' attention: A typographical enhanced study. In C. Doughty \& J. Williams (eds.), Focus-on-form in classroom second language acquisition (pp. 78-99). New York: Cambridge University Press.

Williams, J. (1999). Memory, attention, and inductive learning. Studies in Second Language Acquisition, 21, 1-48. http://dx.doi.org/10.1017/S0272263199001011

Wishnov, R. J. (2000). Hedging your bets: L2 learners' acquisition of pragmatic devices in academic writing and computer-mediated discourse. Second Language Studies, 19, 119-157.

Yoshimi, D. R. (2001). Explicit instruction and JFL learner's use of interactional discourse markers. In K.R. Rose \& G. Kasper (Eds.), Pragmatics in Language Teaching (pp. 223-244). Cambridge: Cambridge University Press. http://dx.doi.org/10.1017/CBO9781139524797.016 
Rezvani, E., Eslami-Rasekh, A., \& Vahid Dastjerdi, H. 